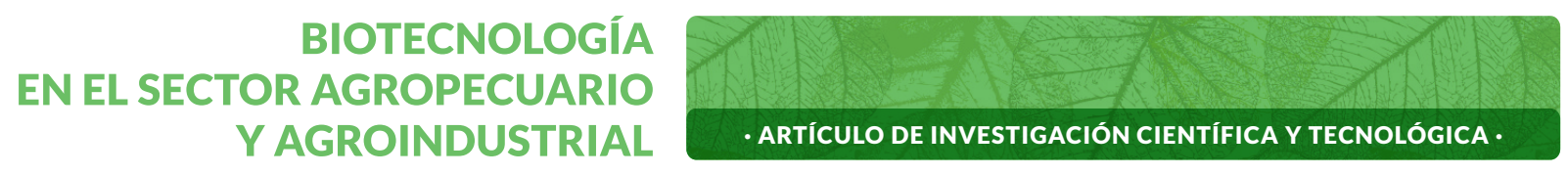

Germination in a venezuelan type of Capsicum chinense jacq.: influence of fruit ripening and seed extraction from the fruit*

\title{
Germinación de un tipo venezolano de Capsicum chinense jacq.: influencia de la maduración del fruto y de la extracción de la semilla desde el fruto
}

\section{Germinação em tipo venezuelano de Capsicum chinense jacq.: influência do amadurecimento de frutas e extracção de sementes do fruto}

GARRIDO, LUZ'; LAURENTIN, HERNÁN²

Historial del Artículo

Recibido para evaluación: 22 de Marzo 2020.

Aprobado para publicación: 3 de Junio 2020.

\footnotetext{
* $\quad$ Proyecto de investigación de origen: "Estudios básicos sobre el ají dulce (Capsicum sp.) para la optimización de su producción hortícola”. Financiación: Consejo de Desarrollo Científico, Humanístico y Tecnológico de la Universidad Centrooccidental Lisandro Alvarado. Culminación: octubre de 2017.

1 Universidad Centroccidental Lisandro Alvarado, Departamento de Ciencias Biológicas, Decanato de Agronomía. Ingeniero Agrónomo. Barquisimeto, Venezuela. https://orcid. org/0000-0003-1020-179X.

2 Universidad Centroccidental Lisandro Alvarado, Departamento de Ciencias Biológicas, Decanato de Agronomía. Ph.D. en Ciencias Agrícolas. Barquisimeto, Venezuela. https:// orcid.org/0000-0001-6222-3566
}

Correspondencia: hlaurentin@ucla.edu.ve 


\section{ABSTRACT}

A type of sweet pepper of the species Capsicum chinense defines the Venezuelan cuisine, but this has not been enough to perform detailed studies of production issues in this crop. To determine the influence of fruit ripening, and seed extraction from the fruit on seed germination of a Venezuelan type of Capsicum chinense, a factorial experiment with 10 replications was conducted. Influence of the six combinations between three fruit maturation levels (green fruits, early-ripe fruits, and totally-ripe fruits) and two seed extraction moments of seed from the fruits (at the same day of the harvest and seven days after the harvest) were evaluated on seed germination percentage and days number to germination. Each replication consisted of 100 seeds, and seed germination was recorded for ten days. Results displayed no interaction between fruit ripening and extraction of seed for both dependent variables, but significant differences $(P<0,01)$ were recorded for germination percentage among fruit ripening levels (the same for totally yellow and fruits changing color, but higher than green fruits), and between separation moment of seed from the fruits (seven days after the harvest resulted in $80 \%$ more germination rate as compared to seed separated at the same day of the harvest). Significant differences $(P<0,01)$ were recorded also for the number of days to germination: seeds extracted from early-and totally-ripe fruits did not have significant differences $(P>0,05)$ and germinated in 7,30 days in average, but they germinated faster $(P<0,01)$ than seeds coming from green fruits which germinated in 8,40 days in average; seeds extracted from fruit 7 days after harvest germinated in 6,50 days in average, faster $(P<0,01)$ than seeds extracted from the fruit the same day of harvest ( 8,75 days in average). Seeds of this type of sweet pepper germinate more abundantly and faster when they are separated from ripening fruits seven days after harvest.

\section{RESUMEN}

El ají dulce de la especie Capsicum chinense caracteriza a la cocina venezolana por el sabor que dan sus frutos. Cabe destacar que en el cultivo hacen falta mas estudios relacionados con su producción. Para determinar el efecto de la madurez del fruto y el momento de extracción de la semilla del fruto sobre la germinación en un tipo de C. chinense venezolano, se llevó a cabo un experimento factorial con 10 repeticiones. Se evaluó el efecto de tres estados de madurez del fruto (frutos verdes, frutos en maduración temprana y frutos totalmente maduros) y dos momentos de extracción de la semilla del fruto (el mismo día de la cosecha y siete días después de la cosecha) sobre el porcentaje de germinación y el número de días a la germinación. Cada repetición consistió de 100 semillas, y la germinación fue registrada durante 10 días. Los resultados no mostraron interacción entre madurez del fruto y momento de extracción de la semilla sobre ambas variables dependientes, pero sí mostra-

\section{KEYWORDS:}

Sweet pepper; Fruit maturation; Number of days to germination; Capsicum chinense jacq.

\section{PALABRAS CLAVE:}

Ají dulce; Maduración del fruto; Número de días hasta la germinación; Capsicum chinense jacq.

\section{PALAVRAS-CHAVE:}

Piment doce, Maturação do fruto, Número de dias até a germinação, Capsicum chinense jacq
Cómo citar este artículo: Garrido, LUZ; Laurentin, Hernán. Germination in a venezuelan type of Capsicum chinense jacq.: influence of fruit ripening and seed extraction from the fruit. Biotecnología en el sector agropecuario y agroindustrial, v. 19, n. 1, 2021, p. 45-53. Doi: https://doi.org/10.18684/BSAA(19)45-53 
ron diferencias $(P<0,01)$ para el porcentaje de germinación entre los niveles de madurez del fruto (igual para frutos en maduración temprana y totalmente maduros, pero más alto que para frutos verdes), y entre los dos momentos de extracción de la semilla del fruto (siete días después de la cosecha resultó en un $80 \%$ más de germinación con respecto a las semillas separadas el mismo día de la cosecha). Del mismo modo se encontraron diferencias para número de días a la germinación: semillas extraídas de frutos en maduración temprana y frutos totalmente maduros no mostraron diferencias $(P>0,05)$, y germinaron en 7,30 días en promedio, pero su germinación fue más rápida que la de las semillas obtenidas de frutos verdes las cuales germinaron en 8,40 días en promedio; las semillas separadas del fruto siete días después de la cosecha germinaron en 6,50 días en promedio, más rápido $(P<0,01)$ que las semillas separadas del fruto el mismo día de la cosecha (8,75 días en promedio). Las semillas de este tipo de ají dulce germinan de manera más abundante y más rápidamente cuando son separadas de frutos maduros siete días luego de cosecharlos.

\section{RESUMO}

Um tipo de pimenta doce da espécie Capsicum chinense define cozinha venezuelana, no entanto, isso não foi suficiente para realizar estudos detal hados de vários aspectos da produção nesta cultura. Para determinar a influência do amadurecimento e extração de sementes do fruto na germinação de um tipo venezuelano de Capsicum chinense, foi realizado um experimento fatorial com 10 repetições. Influência das seis combinações entre três níveis de maturação dos frutos (frutos verdes, frutos maduros e frutos totalmente maduros) e dois momentos de extração de sementes dos frutos (no mesmo dia da colheita e sete dias após a colheita) foram avaliados quanto à porcentagem de germinação das sementes e número de dias até a germinação. Cada replicação consistiu em 100 sementes e a germinação das sementes foi registrada durante dez dias. Os resultados não mostraram interação entre amadurecimento e extração de sementes para ambas as variáveis dependentes, mas foram registradas diferenças significativas $(P<0,01)$ para a porcentagem de germinação entre os níveis de amadurecimento dos frutos (o mesmo para o amarelo e a mudança de cor dos frutos, mas superior ao verde frutos) $e$ entre o momento da separação das sementes dos frutos (sete dias após a colheita resultou em $80 \%$ mais taxa de germinação em comparação com as sementes separadas no mesmo dia da colheita). Diferenças significativas $(P<0,01)$ foram registradas também para o número de dias para a germinação: as sementes extraídas de frutos maduros e totalmente maduros não apresentaram diferenças significativas $(P>0,05)$ e germinaram em 7,30 dias em média, mas germinaram mais rapidamente $(P<0,01)$ do que sementes provenientes de frutos verdes que germinaram em 8,40 dias em média; as sementes extraídas dos frutos 7 dias após a colheita germinaram em 6,50 dias em média, mais rápido $(P<0,01)$ do que as sementes extraídas dos frutos no mesmo dia da colheita (8,75 dias em média). As sementes deste tipo de pimenta doce germinar mais abundantemente e mais rapidamente quando separados de frutas maduras sete dias após a colheita deles.

\section{INTRODUCTION}

Pepper (Capsicum chinense Jacq.) is a species belonging to the plant family Solanaceae, which comprises herbaceous and perennial plants. This species domesticated in Amazonas basin [1], is grown and consumed in many parts of the world. It is worldwide recognized for the fruit pungency, especially by cultivar "Habanero", however, C. chinense has a large genetic diversity [2], mainly in South America, including many non-pungent types. For these authors, Venezuelan accessions present a high genetic variability, therefore this country is considered as diversity center of the crop. Venezuelan cuisine is characterized by the flavor given by fruits of $C$. chinense [3], which belong to the non-pungent types. It is named "sweet pepper" in this country to differentiate it of the pungent types "chilli pepper". It is used for sauce and stew elaboration for meats and fishes. Despite of the great importance of this kind of "sweet pepper" in Venezuela, there is a little knowledge about the crop. Some studies about horticultural management have been carried out, such as transplant time [4], pruning [5], disease control [6], irrigation [7], however, there is a little knowledge about seed in this species [8], and there is no previous studies about seed germination in this Venezuelan type of $C$. chinense except the carried out for evaluating priming with potassium nitrate [9].

Knowledge of the conditions required for maximum germination is an important key fact to optimize plantlets production. Farmers complain about low and uneven germination for $C$. chinense [9], observation indicated not only for 
this species, but also for the five domesticated species of Capsicum genus [10]. High, fast, and uniform germination is desirable for planning production, therefore is necessary to get information for optimizing germination process. Seed germination in Capsicum genus is influenced by dormancy [11], and seed development [12], among others factors. Seed pre-conditioning, and priming are some of the strategies used for increasing germination in Capsicum genus $[10,13,14,15]$, however, for $C$. chinense is not known if seed development, as consequence of moment of fruit harvest and moment of seed extraction of the fruit, could be the cause of poor germination. These aspects are necessary to know them in order to be more precise to design strategies to optimize germination in "sweet pepper" C. chinense.

The objective of this research was to determine the influence of fruit ripening, and seed extraction from the fruit, on germination percentage and number of days to germination of one variety of the Venezuelan type of $C$. chinense called "sweet pepper".

\section{METHOD}

\section{Plant material}

Thirty plantlets of "sweet pepper" of $C$. chinense species, belonging to the cultivar "Rosita" were obtained from a recognized nursery in Quibor, Lara state, Venezuela. These plantlets were transplanted individually in bags containing $3000 \mathrm{~cm}^{3}$ of substrate (sand and clay soil 1:1). They were irrigated twice a week until fruits used for the experiment were obtained.

\section{Seeds extraction}

Each plant was considered suitable to get fruits for the experiment after 3 fruits were totally developed at the plant, which occurred around the day 45 since the transplant date. Fruits for each plant were harvested in the following way: two just when on the green fruit appeared the first light green line (these fruits were called green fruits), two when half of the fruit was yellow and the other half remained green (these fruits were called early-ripe fruits), and the last two ones just when fruits became totally yellow (these fruits were called totally-ripe fruits). At the end, sixty green fruits, sixty early-ripe fruits, and sixty totally ripe fruits had been harvested. For each of the three fruit categories, half of the fruits were opened and seeds were taken (these seeds were called seeds extracted at day 1), and half of the fruits remained at room temperature (about $28^{\circ} \mathrm{C}$ ) and were opened 7 days after harvest to obtain the seed (these seed were called seeds extracted at day 7). Fruit harvest and seed extraction were synchronized to start germination tests for all the treatments at the same day, it means, a day named day 0 were harvested 30 green fruits, 30 early-ripe fruits, and 30 totally ripe fruits, for all these fruits seeds were kept inside of the fruits. At the day named day 8 were harvested 30 green fruits, 30 early-ripe fruits, and 30 totally ripe fruits, and seeds were extracted from these fruits; furthermore seeds were collected from fruits harvested at the day 0 .

\section{Experiment design}

A completely random experiment design with six treatments and ten replication was established in Agua Viva (512 meter on sea level, average temperature of $26^{\circ} \mathrm{C}$, average relative humidity of $75 \%$ ), Palavecino Municipality, Lara state, Venezuela. The treatment design was a factorial $3 \times 2$, where main factors were Maturation of the Fruit and Extraction Moment of the Seed, the first one with three levels (green fruits, early-ripe fruits, and totally ripe fruits), and the second one with two levels (seeds separated at day 1 , and seeds separated at day 7). Experimental units were germination chambers (anime trays $20 \times 12 \mathrm{~cm}$ as support of paper towel, covered with transparent plastic cover $10 \mathrm{~cm}$ height), one per replication, containing 100 seeds recorded for germination. 


\section{Germination tests}

One hundred seeds for each experimental unit were used for germination tests. Seeds were placed in germination chambers at room temperature (about $27^{\circ} \mathrm{C}$ in average). Germination was recorded for each experimental unit during 10 days, so close to the period used by Hernandez et al. (2019) [16] for evaluating germination in C. chinense. Germination percentage for each day, and over the ten days, was calculated. Seeds were considered germinated when the radicle emerged. Number of days to germination, was calculated as a weighted average according the amount of seeds germinated at each day.

\section{Data analysis}

Variance analysis were performed for germination each day and over all the days, and also for number of days to germination; considering the main factors and their interaction. Variables resulting in statistical differences were subjected to Tukey mean test. All the statistical analyses were performed with Statistix for Windows v. 8.0.

\section{RESULTS}

Evaluation of seed germination in six combinations between three fruit maturation stages and two moments of seed extraction from the fruits resulted in data showed in Figure 1. Germination started at day 3 for seeds coming from totally-ripe fruits and separated at day 7 Interaction for Maturation of the Fruit and Separation Moment of the Seed did not show significant differences $(P>0,05)$ neither for Germination Percentage (for each day or over all the days) nor for Number of Days to Germination. Germination percentage for fourth, fifth, sixth, and seventh day of evaluation showed differences $(P<0,01)$ only for Moment of Seed Separation: germination for seeds separated of the fruit at day 7 was in average 10 -fold higher $(P<0,01)$ than germination percentage of seeds separated of the fruits at day 1 (Figure 2). Germination percentage accumulated on the ten days of evaluation displayed statistical differences $(P<0,01)$ for both main factors (Figure 3); totally- and early-ripe fruits had germination over $60 \%$ while green fruits did not reach $50 \%$. Seeds separated 7 days after fruits harvest had more than $80 \%$ of germination, while seeds separated the same day of the fruits harvest reached only $34 \%$ of germination. Number

Figure 1. Germination percentage for six treatments in a Venezuelan type of "sweet pepper" C. chinense during 10 days (GF is green fruits, ERF is Early Ripe Fruits, TRF is Totally Ripe Fruits, SE1 is Seed Extracted from the Fruit at Day 1, SE7 is Seeds Extracted from the Fruit at Day 7).

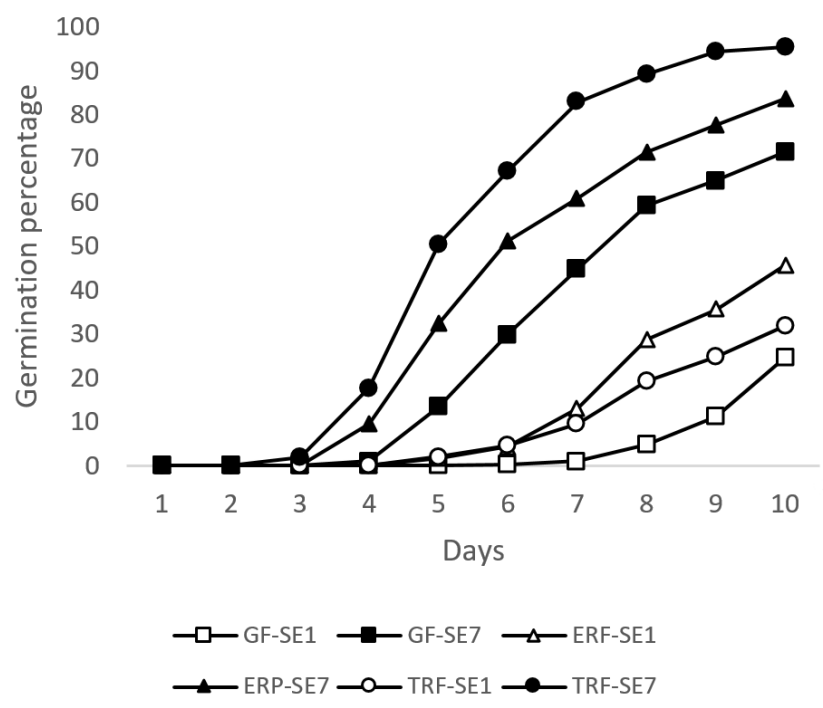


Figure 2. Germination percentage for seeds separated of the fruit at the harvest day, and 7 days after harvest, at fourth, fifth, sixth, and seventh day of germination evaluation. Means represented with different letters showed statistical differences $(P<0,01)$.

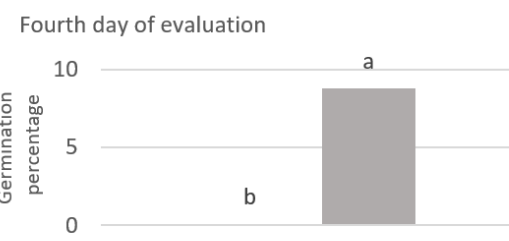

- Seeds separated of the fruit the harvest day

- Seeds separated of the fruits 7 days after harvest

Sixth day of evaluation

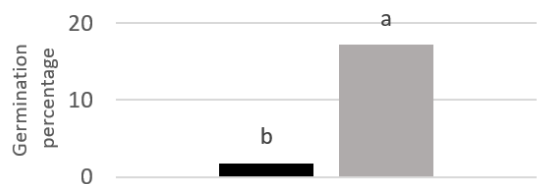

- Seeds separated of the fruit the harvest day

Seeds separated of the fruits 7 days after harvest
Fifth day of evaluation

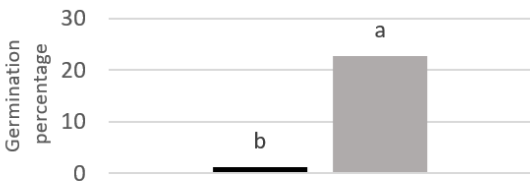

- Seeds separated of the fruit the harvest day

- Seeds separated of the fruits 7 days after harvest

Seventh day of evaluation

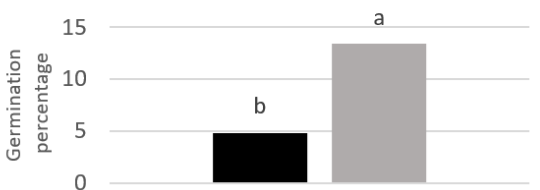

- Seeds separated of the fruit the harvest day

Seeds separated of the fruits 7 days after harvest

Figure 3. Germination percentage after ten days of evaluation, for three maturation stages of the fruit, and two moments of seed separation of the fruits. Means represented by the same letter does not have statistical differences $(P>0,05)$
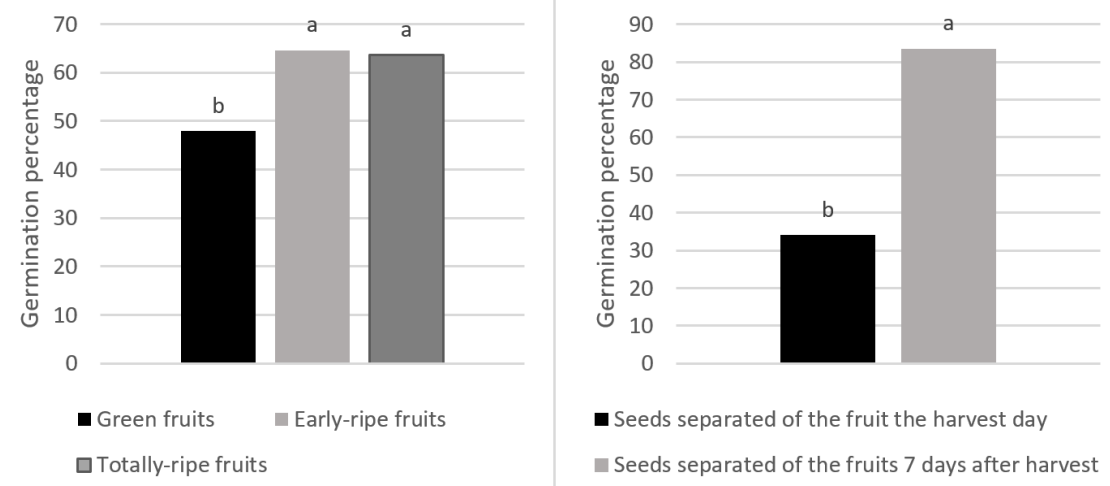

of days to germination resulted also with differences $(P<0,01)$ for the main factors evaluated (Figure 4). While seeds obtained from green fruit germinated in $8,40 \pm 1,49$ days, seeds obtained from early-ripe fruits germinated in $7,56 \pm 1,48$ days, and from totally-ripe fruits in $7,05 \pm 1,66$ days. More evident for number of days to germination is the effect of moment of seed separation of the fruits: $6,50 \pm 1,28$ days for seeds separated from the fruits at day 7 after harvest, and 8,75 $\pm 0,94$ for seeds separated from the fruit the same day of the harvest.

Production of high quality seeds depends, among several factors, on appropriate harvest time [17]. Results of the present work indicate that percentage of seed germination and number of days to germination in $C$. chinense is affected by ripening of the fruits, and moment of seed separation from the fruit. Complain of farmers about uneven germination and low germination percentage $[9,10]$ could be caused by lack of uniformity in ripening level of fruits harvested to get seeds, and/or lack of uniformity in moment of seed separation from the fruits. Most of the attempts to overcome the problem of low germination percentage in C. chinense and other species of the 
Figure 4. Days in average to germination after ten days of evaluation, for three maturation stages of the fruit, and two moments of seed separation of the fruits. Means represented by the same letter does not have statistical differences $(P>0,05)$

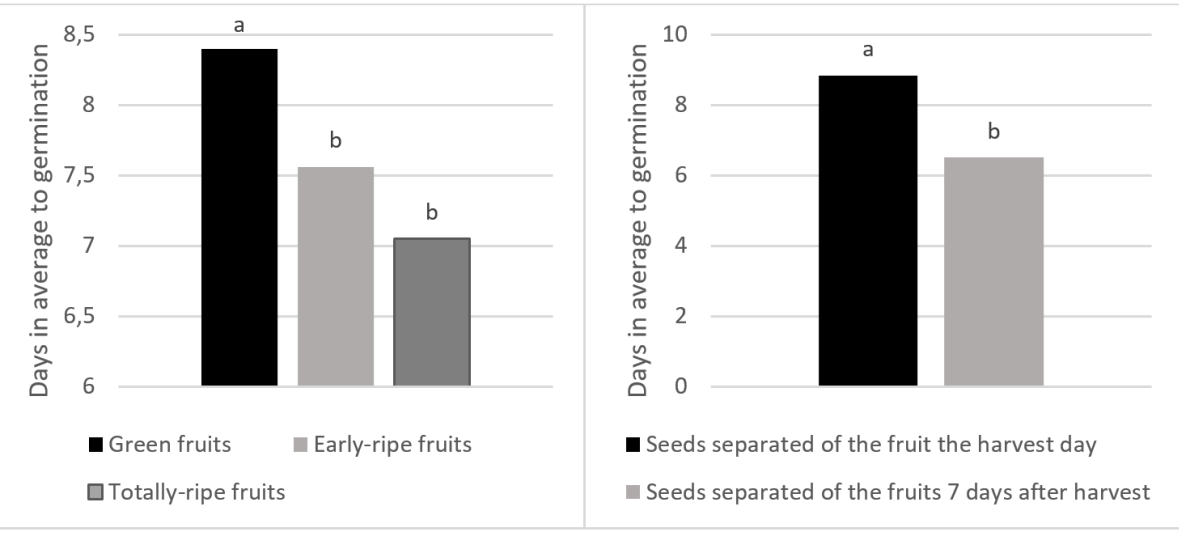

genus Capsicum have been based in use of adequate substrates [18], priming strategies [9,10,12], or studies about optimal seed storage [19], however, there is no reports about systematic comparison among germination percentages and number of days to germination of seeds coming from different ripening fruits levels or different moment of seed separation from the fruits. According to results of this research, green fruits should not be harvested to get seeds due to the low germination percentage and higher number of days to germination. Low germination percentage in immature fruits of $C$. chinense is due to the absence of some reserve substances in the seeds caused by insufficient physiological maturity [20]. To harvest early-ripe fruits, or totally-ripe fruits has the same effect on germination percentage and number of days to germination, increasing germination percentage in about $15 \%$ as compared to seeds coming from green fruits; and accelerating the time to obtain germination in about 1 day (from 8,4 days in green fruits to 7,3 days in early- and totally-ripe fruits). Maximum germination of seeds in the period of 71-81 days after anthesis was found in pepper (Capsicum baccatum) seeds [17]; this result differs as compared to results of present work, where maximum germination occurred with early-ripe fruits, and this fruit state occurred about day 55 after anthesis.

Fruits and therefore seeds of these species are consumed by birds, and digestive tract acts on seed to become them suitable for germination [21]. It is possible that, if seeds are kept inside the fruits as in the present research, they are subjected to the action of some fruit metabolites which appear after fruit is harvested, it means, when decomposition of the fruit starts, giving the opportunity to become the seed ready to germinate, in a similar way as bird digestive tract acts on the seeds of $C$. chinense. This theory could explain the fact that seeds separated from the fruit 7 days after harvest had higher germination percentage and faster germination speed than seed which did not have the chance to be subjected to the action of the fruit metabolites. Exogenous capsaicin application $(0,1 \mathrm{ppm})$ to seeds of $C$. annuum increased germination percentage and shortened germination time [22], and, considering that the type of Venezuelan "sweet pepper" evaluated in the present work belongs to the genus Capsicum, it could be possible that minimal levels of capsaicin are produced in the fruit and affect percentage and speed of germination. Capsaicinoids levels and maximum amount produced depends, among other factors, on $C$. chinense cultivar or accessions, and they increases according to ripening of the fruit [23]. Water stress increases levels of capsaicinoids in C. chinense, [24] and it occurs when fruits are separated from the plant, therefore, it is a possible explanation about faster germination and higher germination percentage in the present work.

\section{CONCLUSIONS}

There is not statistical interaction between ripening fruits levels and moment of seed separation from the fruits when germination percentage and number of days to germination were evaluated in Capsicum chinense culti- 
var Rosita, however, there are effect of these factors individually. Seeds extracted from green fruits had lower germination percentage (48\%) and lower germination speed (8,40 days) than seeds coming from early- $(65 \%$ of germination, 7,56 days to germination) and totally-ripe fruits (64\% of germination, 7,05 days to germination). Seeds separated from the fruit 7 days after harvest had higher germination percentage ( $83 \%$ and 6,50 days) and faster germination speed than seeds separated of the fruits the same day of the harvest (34\% and 8,75 days).

\section{ACKNOWLEDGMENT}

Authors wish to express gratitude to Consejo de Desarrollo Científico, Humanístico y Tecnológico of Universidad Centroccidental Lisandro Alvarado, for support the Project 029-AG-2014 from which this paper was obtained.

\section{REFERENCES}

[1] YUMI-BABA, VIVIANE; ROCHA, KATIA-REAL; GOMES, GISELY-PAULA; RUAS, CLAUDETE-DE FÁTIMA; RUAS, PAULO-MAURÍCIO; RODRIGUEZ, ROSANA; AZEREDO-GONÇALVES, LEANDRO-SIMOES. Genetic diversity of Capsicum chinense accessions based on morphological characterization and AFLP markers. Genetic Resources and Crop Evolution, v. 63, n. 8, 2016, p. 1371-1381. https://doi.org/10.1007/s10722-015-0325-4

[2] PALADINI-MOREIRA, ALINE-FABIANA; RUAS, PAULO-MAURÍCIO; DE FÁTIMA-RUAS, CLAUDETE; YUMI-BABA, VIVIANE; GIORDANI, WILLIAN; MENDONÇA-ARRUDA, ISABELLA; RODEIGUEZ, ROSANA; AZEREDO-GONÇALVES, LEANDRO-SIMOES. Genetic diversity, population structure and genetic parameters of fruit traits in Capsicum chinense. Scietia Horticulturae, v. 236, 2018, p. 1-9. https://doi.org/10.1016/j.scienta.2018.03.012

[3] PASTRAN, FÉLIX. Desarrollo cultural canario-venezolano desde la expresión humana, religiosa, deportiva, gastronómica y agrícola. Revista Chakiñan de Ciencias Sociales y Humanidades, v. 7, 2019, p. 118-134.

[4] MONTAÑO, M.; NELSON, J. Efecto de la edad de trasplante sobre el rendimiento de tres selecciones de ají dulce (Capsicum chinense Jacq.). Bioagro, v. 12, 2000, p. 55-59.

[5] JAIMEZ, RAMÓN E.; NAVA, N.; RIVERO, Y.; TROMPIZ, K. Efecto de diferentes intensidades de poda sobre la dinámica de floración y producción de ají dulce (Capsicum chinense Jacq.). Revista de la Facultad de Agronomía (LUZ), v. 19, 2002, p. 132-139.

[6] CEDEÑO, LUÍS; CARRERO, CHRYSTIAN; JAIMEZ, RAMÓN. Pudrición basal del ají dulce por Haematonectria haematococca en el estado Mérida, Venezuela. Interciencia, v. 28, 2003, p. 590-592

[7] GIL-MARÍN, JOSÉ A.; MONTAÑO-MATA, NELSON; PLAZA, RAMIRO. Efecto del riego y la cobertura del suelo sobre la productividad de dos cultivares de ají dulce. Bioagro, v. 24, 2012, p. 143-148.

[8] AYALA-GARAY, O.J; PINZÓN-LÓPEZ, L.L.; LATOURNERIE-MORENO, L.; AYALA-GARAY, A.V.; TOVAR-CARVAJEL, S. Adaptaciones metodológicas para evaluar la calidad fisiológica en semillas de chile habanero (Capsicum chinense Jacq.). Agroproductividad, v. 11, n. 9, 2018, p. 9-14. https://doi.org/10.32854/agrop.v11i9.1208

[9] ANDRADE, SOELIS; LAURENTIN, HERNÁN. Efecto del nitrato de potasio sobre la germinación de semillas de tres cultivares de ají dulce (Capsicum chinense Jacq.). Revista UNELLEZ de Ciencia y Tecnología, v. 33 , 2015, p. 25-29.

[10] MAVI, KAZIM. Evaluation of organic priming to improve the emergence performance of domesticated Capsicum species. Seed Science and Technology, v. 46, 2018, p. 131-137. https://doi.org/10.15258/sst.2018.46.1.13

[11] CANO-VASQUEZ, ANAID; LÓPEZ-PERALTA, MARÍA-CRISTINA; ZAVALETA-MANCERA, HILDA; CRUZ-HUERTA, NICACIO; RAMÍREZ-RAMÍREZ, IVÁN; GARDEA-BÉJAR, ALFONSO; GONZÁLEZ-HERNÁNDEZ, VÍCTOR. Variación en grados de latencia en semillas entre colectas de chile piquín (Capsicum annuum var. glabriusculum). Botanical Sciences, v. 93, 2015, p. 1-10.

http://dx.doi.org/10.17129/botsci.138 
[12] EKEN, NAZLI-IIKE; MAVI, KAZIM. Determination of relationships between fruit maturity stages and seed development and quality in aji pepper (C. baccatum var. pendulum). Tarim Bilimleri Dergisi, v. 22, 2016, p. 69-76.

[13] HERNANDEZ-LOPEZ, ALEJANDRO; BELTRÁN-PEÑA, ELDA-GUADALUPE; AMANCIO-OLIVEIRA, ANTONIA-ELENIR; NUÑEZ-GAONA, ÓSCAR; AVILA-ALEJANDRE, ALMA-XOCHIL. Preacondicionamiento del agua en la germinación y emergencia de Capsicum chinense Jacq. Revista Mexicana de Ciencias Agrícolas, v. 9, n. 8, 2018, p. 1703-1714. https://doi.org/10.29312/remexca.v9i8.1030

[14] SANDOVAL-RANGEL, ALBERTO; TAPIA-GONZÁLEZ, ALEJANDRA; CABRERA-DE LA FUENTE, MARCELINO; GONZÁLES-FUENTES, JOSÉ-ANTONIO; BENAVIDES-MENDOZA, ADALBERTO. Age, benefit and gibberellic acid affect the germination and production of piquin pepper plant. Revista Mexicana de Ciencias Agrícolas, v. 20, 2018, p. 4199-42019. http://dx.doi.org/10.29312/remexca.v0i20.990

[15] SOSA-PECH, MARINO; RUIZ, ESAU; TUN-SUÁREZ, JOSÉ-MARÍA; PINZÓN, LUÍS. Germinación, crecimiento y producción de glucanasas en Capsicum chinense Jacq. Inoculadas con Bacillus spp. Ecosistemas y Recursos Agropecuarios, v. 6, n. 16, 2019, p. 137-143. http://dx.doi.org/10.19136/era.a6n16.1801

[16] HERNÁNDEZ-LÓPEZ, ALEJANDRO; AVILA-ALEJANDRE, ALMA-XOCHIL; MENDOZA-FRANCISCO, NOE; HERNÁNDEZ-LÓPEZ, HÉCTOR. Design, construction, verification and testing of a low cost germinator. Revista Mexicana de Ciencias Agrícolas, v. 10, n. 2, 2019, p. 431-440. http://dx.doi.org/10.29312/remexca.v10i2.871

[17] CANTUÁRIA-FIGUEIREDO, JOSIANE; SANTOS-DE SOUZA, DAVID-ANDRÉIA; DA SILVA, CLEISSON-DENER; RIBEIRO-AMARO, HUGO-TIAGO; DAVID-ALVES, DORISMAR. Maturacao de sementes de pimenta em funcao de épocas de colheita dos frutos. Scientia Agraria, v. 18, n. 3, 2017, p. 1-7

[18] DAVID-SANTOYA, JESSE-JOEL-EDSON; GÓMEZ-ÁLVAREZ, REGINO; JARQUÍN-SÁNCHEZ, AARÓN; VILLANUEVA-LÓPEZ, GILBERTO. Caracterización de vermicompostas y su efecto en la germinación y crecimiento de Capsicum chinense Jacquin. Ecorsitemas y Recursos Agropecuarios, v. 5, n. 14, 2018, p. 181-190. http://dx.doi.org/10.19136/era.a5n14.1465

[19] KUMAR-VERMA, VEERENDRA; KUMAR-JHA, ANJANI; PATEL, RAMKISHOR; NGACHAN, S.V. Studies on storage life and effect of temperature and pre-sowing seed treatments on germination behaviour and maturity índices in King-chilli (Capsicum spp.). Indian Journal of Agricultural Sciences, v. 88, n. 8, 2018, p. 1162-1167.

[20] MOO-MUÑOZ, A.J.; AYALA-GARAY, O.J.; LATOURNERIE-MORENO, L.; TZEC-MAY, Y.A.; PINZÓN-LÓPEZ, L.L. Efecto de la madurez y secado de semilla de Capsicum chinense Jacq. en la germinación y calidad fisiológica de plántula. Agroproductividad, v. 9, n. 1, 2016, p. 63-67.

[21] MORTENSEN, JONATHAN M.; MORTENSEN, JOEL E. The power of capsaicin. Journal of Continuing Education, v. 11, n. 1, 2009, p. 8-12.

[22] ARIN, LEVENT; ARABACI, ÇAGATAY. The influence of exogenous capsaicin application on the germination, seedling growth, and yield of pepper. Turkish Journal of Agriculture and Forestry, v. 43, 2019, p. 1-8. 10.3906/tar-1903-86

[23] OLGUIN-ROJAS, JOSÉ-ARTURO; FAYOS, ORETO; VÁSQUEZ-LEÓN, LUCIO-ABEL; FERREIRO-GONZÁLEZ, MARTA; RODRÍGUEZ-JIMENES, GUADALUPE-DEL CAMEN; PALMA, MIGUEL; GARCÉS-CLAVER, ANA; BARBERO, GERARDO-F. Progression of the total and individual capsaicionids content in the fruits of three different cultivars of Capsicum chinense Jacq. Agronomy, v. 9, n. 3, 2019, p. 141-155.

10.3390/agronomy 9030141

[24] JEEATID, N.; TECHAWONGSTEIN, S.; SURIHARN, B.; CHANTHAI, S.; BOSLAND, P.W.; TECHAWONGSTEIN, S. Influence of water stresses on capsaicinoid production in hot pepper (Capscium chinense Jacq.) cultivars with different pungency levels. Food Chemistry, v. 245, 2018, p. 792-797.

https://doi.org/10.1016/j.foodchem.2017.11.110 